\title{
AZ 1945-1956 KÖZÖTTI GYŐRI POLITIKAI ÉS KÖZIGAZGATÁSI VEZETŐRÉTEG SZÁRMAZÁSI- FOGLALKOZÁSI ÖSSZETÉTELE ÉS MOBILITÁSI TENDENCIÁI
}

\author{
(The Political and Administrative Elite of Györ \\ between 1945 and 1956 Examined with Regard \\ to their Social Background, Occupation and Tendency to Mobility)
}

\section{VARGA BALÁZS}

Kulcsszavak:

elit helyi elit nómenklatúra káder intergenerációs mobilitás intragenerációs mobilitás

A tanulmány az 1945-1956 közötti györi politikai és közigazgatási vezetőréteg néhány társadalomstatisztikai jellemzójének áttekintésére vállalkozik. Részletesen bemutatásra kerül, hogy a csoport tagjai milyen társadalmi helyzetü családból indultak, közéleti szerepvállalásukat megelözöen milyen eredeti foglalkozással és szakképzettséggel rendelkeztek, valamint milyen nemzedéken belüli és nemzedékek közötti mobilitási esélyeik és lehetỏségeik voltak az érintett korszakban. Az elsösorban levéltári forrásokra épülö vizsgálat megállapította, hogy a helyi vezetỏréteg meghatározó része $(41,8 \%$-a) munkás családból származott, míg a legkevésbé számos csoportot $(7,1-7,1 \%)$ az alkalmazotti és az értelmiségi családból érkezök alkották. A helyi vezetöréteg döntỏ hányada (59,3\%-a) munkás hivatással birt, míg a parasztok (5,3\%) és a kisiparosok/kiskereskedők (3,6\%) visszaszorulása különösen jelentősnek tekinthetö a származásnál megfigyelt adatokhoz képest. Az intergenerációs mobilitás a csoport több mint felét (51,5\%) érintette, míg a legföbb mobilitási iránynak egyértelmüen a munkássá válás tünt.

\section{Bevezetés}

A györi politikai és közigazgatási vezetörétegbe sorolás kritériumai 1945 és 1956 között

A helyi elit-pozíciók Györben 1945 és 1948 között, illetve 1956-ban

Magyarország 1944/1945 és 1956 közötti történelmében két olyan idöszak volt, amikor a vezetô réteg (elit) tagjai demokratikus elvủ kiválasztódás, illetve tudás és teljesítmény révén kerül(het)tek pozícióikba. Györ esetében az első korszak kezdőpontjának 1945. április 6-át, a győri nemzeti bizottság megalakulásának napját, míg szimbolikus végpontjának 1948. február 23-át, Udvaros István, Györ város polgármestere lemondatásának napját tekintjük. Györben 1945 júniusában alakult meg a városi, míg júliusban a vármegyei törvényhatósági bizottság, mely testületek azonban, véleményünk szerint, nem rendelkeztek egyértelmüen a döntéshozatal monopóliumával (mint például a két világháború közti időszakban), így tagjaikat nem 
lehet a város vagy a vármegye elitjének, politikai vezetörétegének tekinteni. A város irányítása, a döntések meghozatala több testület és számos pozíció között oszlott meg. Egyrészt 1947-ig a nemzeti bizottság(ok) párhuzamosan müködtek a törvényhatósági bizottság(okk)al, hatáskörük több területen fedte egymást, így gyakori volt a két testület közti rivalizálás is. Másrészt a korlátozott parlamentarizmus bö három esztendeje alatt a pártok befolyása (Györben kezdetben a Szociáldemokrata Párt és a Magyar Kommunista Párt, később már csak az utóbbi részéről) ugyancsak erőteljesen érvényesült a várospolitikában, így a pártoknak, különösképpen a pártok vezetỏ személyiségeinek igen csak megvolt az esélyük és lehetőségük a döntések alakítására. A második időszak, melyben meglátásunk szerint szintén helyénvaló a helyi (politikai) elit terminusának használata, az 1956-os forradalmi korszak, melyet Győrrel kapcsolatban 1956. október 26. (a Nemzeti Tanács megalakulása) és november 4. (a Dunántúli Nemzeti Tanács megszünése) közé datálunk.

A fentiekböl kiindulva úgy véljük, hogy a koalíciós idöszakban a következö pozíciók betöltóit tekinthetjük a város politikai elitjének: föispán, alispán, polgármester, polgármester-helyettes, nemzeti bizottság elnöke, elnökhelyettese, titkára, az MKP, SZDP, FKgP, NPP városi és megyei titkára, városi és megyei elnöke, illetve a györi választókerület országgyủlési képviselöi közül azok, akik győri kötődésủek vagy több cikluson keresztül képviselték a választókerületet. A politikai vezetörétegbe tartozónak tekintjük még azokat a személyeket is, akik több, de véleményünk szerint kisebb befolyással bíró tisztséget egyszerre láttak el (például egy időben voltak a városi és a vármegyei törvényhatósági bizottságnak is tagjai, vagy valamilyen pártbeosztás mellett képviselőtestületi funkcióval is rendelkeztek stb.).

Az 1956-os forradalom napjai alatt a helyi politikai elitet, nézetünk szerint, az alábbi pozíciók birtokosai alkották: a Györi Ideiglenes Nemzeti Tanács, majd a Dunántúli Nemzeti Tanács elnöke, a Györi Ideiglenes Nemzeti Tanácsban az értelmiségi-, a munkás-, a paraszt- és a közigazgatási tanács elnöke, a Megyei Munkástanács elnöke, a nagyobb gyárak (például a Vagongyár, a Hajtómủgyár) munkástanácsainak vezetỏi, illetve az újjászerveződő pártok (SZDP, FKgP, DNP stb.) megyei és városi vezetöi. A felsorolt tisztségeket betöltőkön kívül a politikai elithez soroljuk még azokat a személyiségeket is, akik ugyan fontosabb konkrét pozícióval nem rendelkeztek, tevékenységükkel mégis nagy hatást gyakoroltak a forradalmi események alakítására (például Tihanyi Árpád).

\section{Nómenklatúra (káder)-pozíciók Győrben 1948 és 1956 között}

1948 februárját-márciusát, Udvaros István polgármester és dr. Borbély Endre föispán pozícióból történő elmozdítását követően, Győr politikai vezetőrétegére vonatkozóan, úgy gondoljuk, már indokoltabb az elit helyett a nómenklatúra (bár az első, a hatásköri lista fogalmát, illetve a párttestületek jogosítványait meghatározó dokumentumnak csak egy későbbi, 1949. augusztus 22-i keltezésủ Szervezö Bizottsági állásfoglalás tekinthető) és a káder terminusait alkalmazni. Györben és a megyében a 
Varga Balázs : Az 1945-1956 közötti győri politikai és közigazgatási vezetöréteg származásifoglalkozási összetétele és mobilitási tendenciái. - Tér és Társadalom 24. évf. 2010/2. 45-61. p.

jelzett időponttól kezdve folyamatosan, nagy számban kerültek ki a helyi hatalmat megtestesítő funkciókból a korábban demokratikusan megválasztott személyek, és egyre inkább a Magyar Dolgozók Pártja különböző szervei nevezték ki, a feltétlen engedelmesség, lojalitás, párt- és eszmehủség elveit szem elött tartva, az új vezetöket a különbözö posztokra.

A legfontosabb pozícióknak, melyek birtokosaikat feljogosították a város (és a megye) sorsát befolyásoló politikai és közigazgatási döntések meghozatalára, az alábbiakat tekintjük: föispán és polgármester (a posztoknak a tanácsrendszer bevezetésével történő megszủnéséig), a nemzeti bizottság elnöke, elnökhelyettese, titkára (a testület 1947-1948-as megszünéséig), a Győr városi tanács végrehajtó bizottságának elnöke, elnökhelyettesei, titkára, a Györ-Sopron megyei tanács végrehajtó bizottságának elnöke, elnökhelyettesei, titkára, az MDP megyei bizottság titkára, az MDP megyei bizottság osztályvezetooi, az MDP városi bizottság titkára, az MDP városi bizottság osztályvezetói, városi függetlenített titkár, az ÁVH megyei vezetöje, a SZOT megyei titkára, a Vagongyár vezérigazgatója, az FKgP megyei titkára, az NPP megyei titkára, a győri választókerület győri kötődésủ országgyülési képviselői (amennyiben a társadalmi megbízatás más, az előbbiekben nem említett fontosabb funkcióhoz kapcsolódik). A felsorolt posztok közül az első ismert, 1950. március 29-i hatásköri listán a következők szerepeltek: a Megyei Pártbizottság titkára (a Politikai Bizottság döntési jogkörébe tartozott), a SZOT megyei titkára, a Megyei Tanács elnöke, a Vagongyár vezérigazgatója (a Titkárság hatáskörébe tartoztak), a megyei pártbizottságok osztályvezetöi, a város függetlenített titkára, a megyei székhely (így Györ város) tanácselnöke (a Szervező Bizottság döntési kompetenciájába estek). A többi pozíció fölött az alsóbb pártszervek, elsősorban a megyei vezetés, rendelkeztek.

Mindegyik idószakkal (1945-1948 és 1956, illetve 1948-1956) kapcsolatban szükségesnek tartjuk megemlíteni, hogy az egyes pozíciók és funkciók különbözó mértékủ döntési kompetenciával bírtak, így nem minden szempontból vehetők egy kalap alá, illetve az említett posztokon kívül más tisztségek is léteztek, melyek betöltói befolyást gyakorolhattak a helyi döntéshozatalra, ezzel együtt úgy gondoljuk, az általunk kiválasztott pozíciókon keresztül jól megragadható a város politikai vezetőrétege a vizsgált korszakban.

A fentiekben meghatározott pozíciókat és besorolási kritériumokat alapul véve és alkalmazva egy 140 föböl álló csoport alakult ki, melynek tagjai az említett korszakban, vagy legalább is annak egy részében, a helyi politikai és közigazgatási vezetőréteghez tartoztak. A 140 fö közül 119 személyre vonatkozóan sikerült hol több, hol kevesebb információhoz jutni (levéltári, sajtó és egyéb források révén), így a vizsgálati mintát is ez a kisebb létszámú csoport jelenti. A kutatás eredményeit és megállapításait erre a 119 fős, elérhető mintára vetítve tekintjük érvényesnek. 
Varga Balázs : Az 1945-1956 közötti győri politikai és közigazgatási vezetöréteg származásifoglalkozási összetétele és mobilitási tendenciái. - Tér és Társadalom 24. évf. 2010/2. 45-61. p.

\section{Származás}

A mintába került 119 fö közül 98-nál (a vizsgálati minta 82,4\%-a) sikerült kideríteni a szülők társadalmi állását, pozícióját. Nehezíti a tényleges kategóriák megállapítását és a pontos analízist, hogy a korabeli forrásokban gyakran olyan általánosságok szerepelnek megjelölésként, mint ,szegény parasztcsalád” vagy ,munkáscsalád". Az efféle társadalmi helyzet bevallása és megjelölése az 1948-tól datálható időszakban előnyt jelentett a pozícióba kerülésnél, így sokan valós társadalmi helyzetüket elhallgatva, ha tehették, munkásként vagy parasztként identifikálták magukat. A klasszikus szocialista rendszer idószakában a párttal szembekerülő egyénekre gyakran az értelmiségi vagy a kulákparaszt származás bélyegét sütötték, melyek egyeseknél megfeleltek, másoknál nem a valós helyzetnek. Ebből következően a későbbiekben közölt adatokat némileg kritikusan kell szemlélni. A vizsgálat során a származás megállapításánál az apa státusát vettük mérvadónak.

A mintában szereplők közül 41 fő $(41,8 \%)$ munkáscsaládból indult (1. ábra). Ehhez a társadalmi csoporthoz soroltuk a nagyipari (20 munkásnál többet alkalmazó) üzemek dolgozóit, a kisipari mủhelyek segédeit, a szolgáltató szektor fizikai alkalmazottait, a kereskedősegédeket, valamint a közlekedési segédszemélyzetet és az irodai altiszteket (Gyáni-Kövér 1998, 294). A munkások kategóriájának magas reprezentáltsága a korábban elmondottakhoz szorosan kapcsolódóan azzal magyarázható, hogy a mintában nagyobb számban szerepelnek olyan személyek, akik 1948-at követően töltöttek be vezetỏ pozíciót, azaz olyan korszakban, amikor a káderek kiválasztásának egyik fỏ sajátossága a már említett munkás (és paraszt) származás favorizálása volt. Az apa konkrét foglalkozását, hivatását szemlélve (ez 41-bỏl 27 személynél ismert) nagyon színes képpel találkozhatunk. A legszámosabb csoportot ( 5 fővel) a MÁV-dolgozók összevont kategóriája (vasúti kisegítő munkás, fékező, segédfékező, vasúti munkás, mozdonyvezetỏ) jelenti. A második helyen (3-3 fó) a vagongyári munkások meglehetősen tágan értelmezhető csoportja, valamint a kőmủves segédek állnak. A további szakmák mind-mind 1-1 fővel képviseltetik magukat a mintában: nyomdász, asztalos, uradalmi fógépész, hentessegéd, csavargyári segédmunkás, kovácssegéd, bányász, lakatossegéd, cipészsegéd, mázolósegéd, téglagyári munkás, mủbőrmintázó, géplakatos, vas- és fémöntő, kereskedősegéd (majd vasúti írnok és gyors-fényképész), segédmunkás. A felsorolásból kitünik, hogy a munkás származású helyi vezetók édesapjainak túlnyomó része csak kevésbé megbecsült és rosszabb megélhetési lehetóséget biztosító segéd-, illetve betanított munkát végzett, tehát a munkásság csoportján belül is inkább az alsóbb rétegekben helyezkedett el. A mintában mindössze két ún. „elitebb" szakma fordul elö. Gódor Ferencnek, az MKP Megyei Bizottság Agitációs és Propaganda Osztály vezetőjének (1946. július-1948. május) édesapja mozdonyvezetőként ( $M O L$ 1957), míg Szabó Györgyé (a Györi Ideiglenes Nemzeti Tanácsban a munkástanács elnöke) nyomdászként dolgozott (OSZK én., 2). 
Kisiparos (önálló, zömmel segéd nélküli vagy 1-3 segédes mühelytulajdonosok [Gyáni-Kövér 1998, 258]) és kiskereskedő (összevontan: kispolgári) családok gyermekei relatíve magas számban képviseltetik magukat a helyi vezetörétegben. Ebböl a társadalmi csoportból a mintában szereplők közül 19 fö (19,4\%) származott ( 1. ábra). A kategórián belül a kommunista/MDP-s személyiségek dominanciája érhető tetten, akik 13 fővel képviseltetik magukat. Az édesapa pontos szakmája 16 személlyel kapcsolatban volt egyértelmủen beazonosítható. Ez alapján 3 egyénnél a családfö cipész, míg 2 személy esetében hentes hivatást ủzött. 1-1 fö apja szatócs, borbély, férfiszabó, csizmadia, bádogos, bơrványoló tímár, hajoács-kádármester, patkoló- és kocsi kovács, autószerelő-mester, vaskereskedő, míg 1 személyé háztulajdonos volt.

Az östermeléshez-mezőgazdasághoz (mely kategóriát két csoportra bontva elemezzük) kapcsolódó származás szintén gyakran fordul elö a vizsgálati mintában (1. ábra). Uradalmi cseléd, zsellér, földmunkás és agrárproletár eredetủ famíliákból 11 fö (11,2\%) jött, egy személy kivételével mindnyájan a Magyar Kommunista Párt és a Magyar Dolgozók Pártja színeiben folytattak politikai-közéleti tevékenységet. Paraszt (törpe, kis- és középbirtokos) ősökkel 13 fö (13,4\%) rendelkezett. A társadalmi helyzetre vonatkozó meghatározások túlságosan sematikus volta miatt csak annyi bizonyos, hogy a mintába kerültek közül 2 fö (két parasztpárti tisztségviselö) született biztosan törpebirtokos családba. Dr. Tézsla Józsefnek, Győr-MosonPozsony k. e. e. vármegye alispánjának (1945. június-1946. január) szülei hagyma-, illetve tormakertészettel foglalkozó parasztok voltak ${ }^{1}$, míg Szarvas Imrének, a Nemzeti Parasztpárt Györ-Sopron megyei titkárának (1949-töl) szuilei 4 kat. hold földön dolgoztak ${ }^{2}$. Nagy valószínüséggel ugyancsak ehhez a csoporthoz sorolhatjuk dr. Szilágyi Gábort, Győr-Moson-Sopron vármegye alispánját (1947. március1950. április) és Zámbó Józsefet, a Dolgozó Ifjúság Szövetsége Győr-Sopron megyei titkárát (1950-1955), akiket a különbözỏ forrásokban szegényparaszt családból érkezőnek aposztrofálnak ${ }^{3}$ (MOL 1959). A törpebirtokos és a kisbirtokos lét határáról (6. kat. hold föld) egy MKP/MDP-s politikus - Kozma József, országgyủlési képviselő (Marelyn Kiss-Vida 2005, 239) -, valamint egy NPP/MDP-s tisztségviselö - dr. Kéri József, Győr-Sopron megye föügyésze (1954-1956), a Dunántúli Nemzeti Tanács tagja (OHA 1984) - indult. Nem meglepó módon középparaszt és kulák paraszt családok sarjaival elsősorban a Független Kisgazda Párt soraiban találkozhatunk. Ebből a társadalmi közegból került a helyi vezetỏrétegbe Lates József, az FKgP Győr városi elnöke (1946. szeptembertől), az FKgP Ideiglenes Intéző Bizottságának alelnöke (1956. november 1-töl) (Gyáni-Kövér 1998, 270); Kiss Sándor, az FKgP megyei elnöke (1948-ig), az FKgP Ideiglenes Intézö Bizottságának elnöke (1956. november 1-töl) (ÁBTL-106 én.); valamint dr. Modrovits István, az FKgP megyei fötitkára (1946-ban, illetve 1956. november 1-től) (ÁBTL-1 én.). Két kommunista párti politikus szintén az említett társadalmi álásból startolva jutott politikai-közigazgatási pozícióba Györben és a megyében. Szili Ferencnek, a győri Nemzeti Bizottság titkárának (1946. augusztustól), az MKP Győr városi szervezete 
kádervezetöjének szülei középparasztok voltak ( $A B B L-1$ én.), míg Sárosi Jánosnak, az MDP Győr-Sopron megyei Bizottsága Párt- és Tömegszervezetek Osztálya vezetőjének (1950-1952), az MDP Györ-Sopron megyei Bizottsága másodtitkárának (1952-1957) édesapját a káderanyagokban kuláknak minősítik, persze nem felejtik el megemlíteni, hogy Sárosi vele már 1930 óta nem tart kapcsolatot, mivel anyjával azóta különváltan él. Hozzáteszik azt is, hogy az apa a „felszabadulás” előtt kiszökött külföldre, akiről onnantól semmit sem tudnak (MOL 1956). Ezzel Sárosi származásából fakadó hátrányát sikerült is semmissé tenni.

\section{1. ÁBRA}

Származás szerinti megoszlás az apa pozíciója szerint, $N=98$

(Breakdown by Origin, on the Basis of the Father's Position)

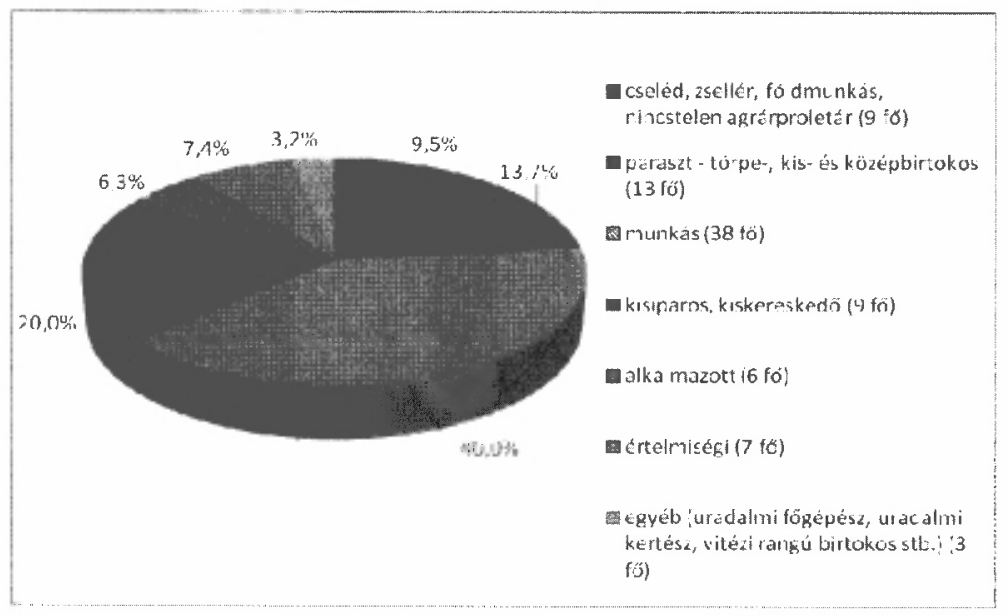

Forrás: Levéltári és archívumi források alapján saját szerkesztés.

A mintában az alkalmazott és az értelmiségi csoport részvétele nem mondható jellemzőnek. Elöbbi kategóriához 7 személy $(7,1 \%)$ tartozik (1. ábra), kiknek apjai katonatisztként, bírósági végrehajtóként, vasúti tisztviselőként, postaellenőrként, MÁV tisztként, illetve városi fószámvevőként tevékenykedtek. Egy esetben, Kardos Mártonnal, az MDP Györ-Sopron megyei Bizottsága Agitációs és Propaganda Osztály vezetőjével (1950-1954) kapcsolatban, az apa pontos foglalkozása nem volt beazonosítható, de társadalmi helyzetként a forrásban az ,alkalmazotti család" volt megjelölve ( $M O L$ 1955a). Utóbbi csoportba szintén 7 fö $(7,1 \%)$ sorolható. Négy esetben a konkrét hivatásra is sikerült rálelni, ezek a következök: vármegyei főlevéltáros, gimnáziumi tanár, kereskedelmi iskolai tanár és tanító. Az értelmiségi pozícióból indulók esetében megfigyelhető, hogy mindegyikőjüknek sikerült, a család kulturális tőkéjét kihasználva, diplomát - többségüknek jogi doktorátust - szerezni, mely általában a státuszmegőrzést is maga után vonta. Ez a megállapítás név szerint az alábbi személyekre érvényes: dr. Alapy Gyula, a györi államügyészség vezetője (1947. júniustól), az SZDP Központi Ellenörző Bizottságának 
titkára (1948. márciustól); dr. Horváth József, Győr város polgármester-helyettese (1945. július-1945. december), az FKgP Ideiglenes Intéző Bizottságának tagja (1956. október 31-től); dr. Petrovich Ferenc, az MDP Györi Végrehajtó Bizottsága közigazgatási felelőse (1948. májustól); dr. Csincsák Endre, a Megyei Munkástanács tagja, a szakszervezeti bizottság elnöke (1956. október-december); dr. Bálint Károly, a városi Értelmiségi Tanács tagja (1956. október-december); Jobbágy Kálmán, a Vagongyári Munkástanács tagja, a Munkástanács delegáltja a Megyei Tanácsban (1956. október-december) és Tárnok Gyula, SZDP titkár, az MDP Győri Végrehajtó Bizottságának kulturális megbízottja (1948. márciustól). Az értelmiségi famíliába születettek között, talán nem meglepö módon, négy olyan személy akad, aki az 1956-os forradalom idején különböző pozíciókban ugyan, de egyértelmủen a demokratikus átalakulás irányába fejtett ki tevékenységet.

A család társadalmi helyzetének megítélésekor a vizsgált korszakban (is) az apa státusa volt a mérvadó, ennek ellenére úgy véljük, érdekes lehet megvizsgálni az anyák hivatását is. A mintába kerülők közül 17 fővel kapcsolatban sikerült felderíteni az anya foglalkozását. Az alacsony elemszám fö oka, ahogyan arról már fentebb szóltunk, hogy a különböző dokumentumok jelentős részében csak az apa pozícióját szerepeltetik, vagy csak a család társadalmi helyzetét rögzítik általánosságban (pl. parasztcsalád, munkáscsalád, értelmiségi család), melynek során az anya státusát tulajdonképpen beolvasztják az apáéba. Mindezekböl kiindulva az alábbi szakmák fordulnak elő az anyák körében: $4-4$ fö gyári munkásnő, illetve háztartásbeli, 3 személy cseléd, 2 fő mosónő, míg 1-1 személy orvosi asszisztens, házvezetőnő, varrónő, illetve szövőnő. A foglalkozások között, mint látható, tipikus női, elsősorban az alsóbb társadalmi rétegekre jellemző szakmákat találunk. A háztartásbeli pozíció kialakulásának előfeltétele, illetve oka az átlagosnál jobb apai státuz (például Szigethy Attila, a Dunántúli Nemzeti Tanács elnöke esetében, kinek apja bírósági végrehajtó volt) (MOL 1955b), vagy a magas gyermeklétszám (például Szántó Zoltán, az MKP Észak-dunántúli Területi Bizottság titkára és Medey István, az SZDP GyőrMoson-Pozsony megyei titkára, országgyülési képviselő szüloöi családjában) volt.

\section{Eredeti foglalkozás és szakképzettség}

A helyi vezetőréteg eredeti foglalkozás szerinti összetételének vizsgálatát megnehezíti, hogy számos egyénnel kapcsolatban a különböző dokumentumok gyakran több, eltérő jellegủ hivatást is feltüntetnek. A könnyebb áttekinthetőség érdekében az elemzésben minden személlyel kapcsolatban csak egy foglalkozást szerepeltetünk, az eredeti foglalkozásnak az első megszerzett szakmát tekintjük. Ahol rokon területek adódnak, ott összevont kategóriákat alkalmazunk.

A vizsgált egyének foglalkozási megoszlása rendkívül tarka képet mutat. 113 személy (a teljes minta 95\%-a) 40 szakmán és foglalkozási csoporton osztozik. A mintában a legnagyobb számban (12 fỏvel) a főhivatású közigazgatási tisztviselők és közhivatalnokok (állami, megyei, járási és városi tisztviselők, rendőrségi alkalma- 
Varga Balázs : Az 1945-1956 közötti győri politikai és közigazgatási vezetőréteg származásifoglalkozási összetétele és mobilitási tendenciái. - Tér és Társadalom 24. évf. 2010/2. 45-61. p.

zottak) képviseltetik magukat. Közülük többen (pl. dr. Velsz Aladár, dr. Borbély Endre, dr. Tóth István) a későbbi karrierjük során - jogtudományi végzettségüknek köszönhetően - ügyvédként is praktizáltak. A második legnépesebb kategóriát (9 fö) a lakatos(segéd) szakmát ủzők alkotják. A hivatás gyakori előfordulása a foglalkozás korabeli elterjedtségével magyarázható, különösen Győrben, az ipari központban.

A mintában 8-8 olyan személy akad, akinek eredeti foglalkozása másik két úgynevezett „divatszakma”: az asztalos(segéd), illetve a vasesztergályos(segéd) hivatás volt. Szövőként és textilmunkásként 6 személy, míg tanítóként/tanárként/egyetemi tanársegédként, villanyszerelöként, mérnökként (gépész-, bánya-, valamint textilmérnök), valamint földmüvesként 5-5 fö tevékenykedett.

A helyi vezetőrétegben négyen kereskedőként keresték a kenyerüket. Kőmüves(segéd), MÁV-alkalmazott (és munkás), müszerész, nyomdász, illetve autó- és motorszerelő egyaránt 3-3 fỏ található a vizsgálati mintában. Ketten-ketten cipészként, technikusként, illetve gyári tisztviselőként dolgoztak.

Ügyvédi praxisából két fỏ (dr. Meixner Ernő és dr. Bálint Károly) származtatta jövedelmének jelentős részét. Ügyészi, pontosabban népügyészi hivatást a mintában szereplök közül, jellemzö módon, két, 1948 folyamán a SZDP-ből az MDP-be igazoló személy (dr. Alapy Gyula és dr. Petrovich Ferenc) üzött. Elöbbi személy pályája legelején - Érsekújváron rövid ideig ügyvédkedett is (Marelyn Kiss-Vida 2005, 401). A kommunista párton belül 1948 környékén égető problémának mutatkozott a jogi „értelmiség" hiánya; a problémát egyes kádereik ilyen irányú továbbképzésével, illetve a már jogi végzettséggel rendelkezők pártba történő beléptetésével szándékoztak kezelni. Utóbbi jelenséget, Szakolczai Attila szavaival élve, „fordított káderpolitikának" is nevezhetjük (http://server200l.rev.hu).

Az 1-1 fö által üzött szakmák tárháza meglehetősen széles, akad köztiik szobafestő és mázoló, hajóács segéd, kereskedelmi alkalmazott, gépmunkás, fémipari munkás, vagongyári munkás, gazdatisztjjószágkormányzó, tetőfedő, vaskereskedő segéd, szabósegéd, gazdasági cseléd, fütésszerelő, szerszámkészítő, mérlegkészítő segéd, bőripari munkás, kárpitos segéd, cipőtüző, bányamunkás, műszaki rajzoló, valamint színházi rendezỏ és református pap is.

\section{Az intergenerációs és az intragenerációs mobilitás tendenciái}

Az egyes foglalkozásokból társadalmi kategóriákat alkotva képet kaphatunk arról, hogy milyen pozícióból is startoltak saját karrierpályájukon a mintában szereplő egyének. A korszak vezetörétegéböl 67 fö $(59,3 \%)$ a munkásság társadalmi csoportjába tartozik. Az alkalmazotti kategóriához 21 (18,6\%), az értelmiséghez 15 személy $(13,3 \%)$ sorolható, míg a parasztság (földműves, kisgazda) csoportjában $6(5,3 \%)$, a kereskedők között pedig 4 személyt (3,5\%) találhatunk (2. ábra). A kapott adatokat és az apa társadalmi pozíciójánál látott eredményeket a mobilitás-vizsgálatok egyik leggyakrabban alkalmazott módszerével, az ISA-paradigma segítségével vetjük össze. A könnyebb értelmezhetőség kedvéért öt fó társadalmi kategóriát használunk az analízisben. Az értelmiség fogalmát - Gyáni Gáborral egyetértve - azokra az egyetemi 
(föiskolai) diplomát szerző „,zzellemi dolgozók”-ra alkalmazzuk, akik nem szorosan adminisztratív munkát végezve, tehát nem mint tisztviselök töltöttek be értelmiségi funkciót. Ebbe a szúkebb fogalomba beleértjük az összes szabadpályás élethivatást és a nem tisztviselőként alkalmazott szellemi dolgozók némely csoportját, amely így többek között ügyvédeket, orvosokat, tanárokat, mérnököket, papokat, valamint újságírókat és egyéb kreatív értelmiségieket rejt magában (OHA 1997b). Alkalmazottnak az állami és közalkalmazottakat, illetve köztisztviselöket tekintjük, például a városi és a megyei igazgatásban, valamint a rendörségnél dolgozó tisztviselöket, a MÁV-tiszteket, a vállalati tisztviselöket, a katonatiszteket, valamint a technikusi munkakörben (többnyire alsóvezetőként) tevékenykedőket. A (kis)iparos/ (kis)kerekedő kategóriába belesoroljuk az ún. nagykereskedőket is, míg a paraszti társadalmi helyzethez számítunk minden mezőgazdasággal kapcsolatos tevékenységet és állapotot (például gazdasági cseléd, földmüves, kis- és középparaszt stb.). A munkásság csoportját a származásnál elmondottakhoz hasonlóan határozzuk meg.

\section{2. ÁBRA}

Társadalmi helyzet az eredeti foglalkozás alapján, $N=113$

(Social Status by Original Occupations)

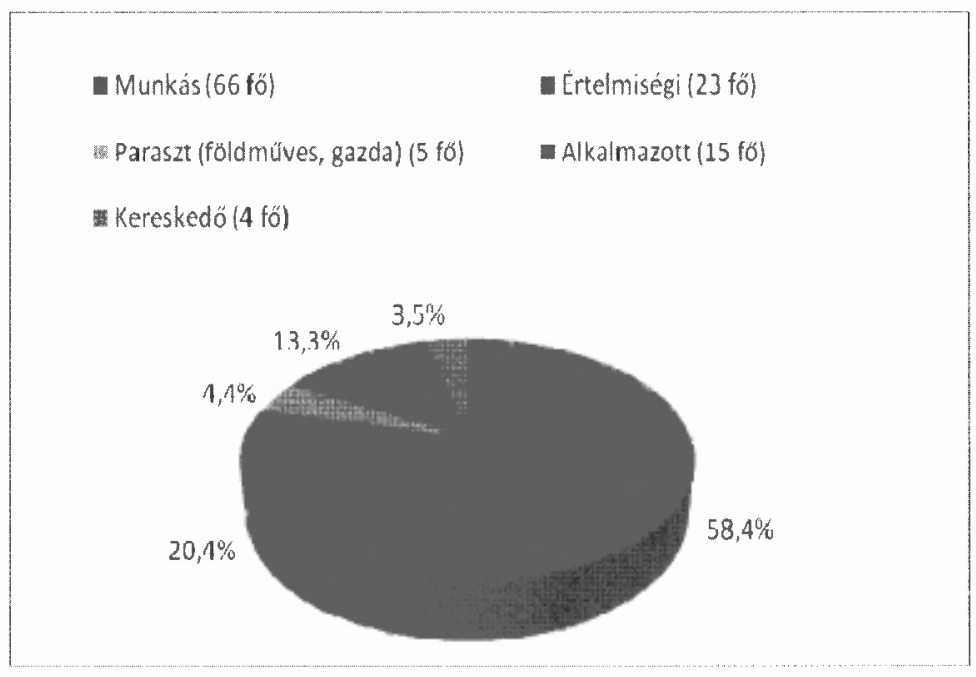

Forrás: Levéltári és archívumi források alapján saját szerkesztés.

A vizsgálati mintában 97 olyan személy $(81,5 \%)$ akad, akivel kapcsolatban lehetőség nyílik az apa társadalmi helyzetének és a saját eredeti foglalkozásnak az öszszehasonlítására, elemzésére. A mobilitási kereszttáblázatok alapján (1., 2. táblázat) egyértelmúen látszik, hogy a 97 egyénből 47 személy (48,5\%) immobilnak, míg 50 fö $(51,5 \%)$ mobilnak tekinthető. Az immobilakat szemlélve megfigyelhetö, hogy az értelmiségi apák gyermekei közül (7 fó) majd' mindenkinek ( 5 személy) sikerült pozícióját megőriznie. Ha az értelmiség tágabb meghatározását alkalmaznánk, azaz a csoporthoz sorolnánk minden felsőfokú végzettséggel rendelkezỏ személyt 
Varga Balázs : Az 1945-1956 közötti győri politikai és közigazgatási vezetöréteg származásifoglalkozási összetétele és mobilitási tendenciái. - Tér és Társadalom 24. évf. 2010/2. 45-61. p.

(a közhivatalok diplomás tisztviselöit is), ahogy azt egyes történészek (pl. Hajdu Tibor) teszik (Gyáni-Kövér 1998), akkor a státuszmegőrzés 100\%-os lenne. $\mathrm{Az}$ értelmiségi családok a sajátos érték- és normarendszerükkel, a tanítás és tanulás iránti elkötelezettségükkel, a kulturális tőkéjükkel egyszerủen predesztinálták gyermekeiket arra, hogy maguk is ebbe a társadalmi kategóriába tartozzanak, másféle, alacsonyabb presztízsü hivatás szinte elképzelhetetlen volt körükben. A csoportban vegyesen találhatunk kisgazda, parasztpárti, 1948-ban az SZDP-ből az MDP-be átigazoló, valamint párton kívüli személyeket. A mintában a hét alkalmazotti származású egyénből két fő sorolható eredeti foglalkozása alapján az apja kategóriájába: Szigethy Attila, országgyülési képviselö (1947-1957), a Győr-Sopron megyei Tanács elnökhelyettese (1950-1954), a Dunántúli Nemzeti Tanács elnöke (1956. október 31-től), akinek az édesapja bírósági végrehajtó volt, míg ő maga tisztviselöként tevékenykedett (Marelyn Kiss-Vida 2005, 401); Dr. Gönczöl Gyula, a Győr-Sopron megyei Tanács V. B. titkára (1953 szeptembertől), a Forradalmi Munkástanács Intéző Bizottságának titkára (1956. november 2-től) eredeti foglalkozását tekintve közigazgatási tisztviselỏ volt, míg apja postaellenőrként dolgozott (MOL 1953). A kisiparos és kiskereskedő családokból érkezők közül senki sem vitte tovább a felmenők hivatását. A 60 munkásként tevékenykedő személyből 34-nek az édesapja maga is munkás volt, míg 6 olyan személy (4 kommunista és 2 kisgazda) akad a mintában, akinél a paraszti háttér az eredeti foglalkozásnál is egyértelmủen visszaköszön. Utóbbi csoportból némileg kilóg dr. Modrovits István (az FKgP megyei fötitkára 1946-ban és 1956. november 1-től), aki jogtudományi végzettség birtokában biztosította megélhetését a földtulajdonából (Bana et al. 1996a, 179).

A kilépési mobilitási arányszámokat tekintve elmondható, hogy az értelmiségi apák gyermekeinek 71,4\%-a maga is értelmiségivé vált már a karrierje elején, míg 28,6\% (2 fö) alkalmazotti, közelebbröl tisztviselöi pozícióba került (1. táblázat).

Az alkalmazotti családból indulók 14,3\%-a (1fó) értelmiségi (Tihanyi Árpád, a Dunántúli Nemzeti Tanács tagja [ÁBTL-1 én.]), 28,6\%-a (2 fö) alkalmazott, míg 14,3\%-a (1 fö) (kis)iparos/(kis)kereskedő lett. Az alkalmazotti háttérrel rendelkezök számára a legfőbb mobilitási iránynak a munkássá válás tekinthető, hiszen $42,8 \%$-uk (3 fö) ehhez a társadalmi csoporthoz tartozott.

A (kis)iparos/(kis)kereskedö felmenőkkel bíró személyek 22,4\%-a (4fỏ) értelmiségi pozícióba került (köztük 2 kommunista, 1 kisgazda és $1 \mathrm{NPP} / \mathrm{DNP}$-s politikus található), míg alkalmazottként 16,7\%-uk (3 fő) dolgozott. A döntő részük (61,1\%, 11 fö), az elözỏ csoportnál megfigyeltekhez hasonlóan, munkássá vált (1. táblázat).

A munkás famíliák gyermekeire az életút elején történö, értelmiségbe való belépés egyáltalán nem volt jellemzö (1. táblázat), mindössze egyetlen személy $(2,4 \%)$ büszkélkedhetett azzal, hogy nagyon gyors és nagyon meredek mobilitást sikerült megvalósítania. Ezt a „sikert” Kecskeméti István, okleveles gépészmérnök, a GyörSopron megyei Tanács Végrehajtó Bizottságának elnökhelyettese (1954-1980) (Bana et al. 1996b, 545) tudhatta a magáénak. Ugyan Kecskeméti rövid ideig munkásként is dolgozott, diplomáját azonban fiatalon, már 24 esztendős korában megszerezte a miskolci Nehézipari Egyetemen, ami után már főművezetői beosztásban 
Varga Balázs : Az 1945-1956 közötti győri politikai és közigazgatási vezetöréteg származásifoglalkozási összetétele és mobilitási tendenciái. - Tér és Társadalom 24. évf. 2010/2. 45-61. p.

TÉT XXIV. évf. 2010 — 2

Az 1945-1956 közötti ... 55

tevékenykedett (MOL 1954). Ebből kifolyólag indokoltnak tartjuk őt ennél a csoportnál figyelembe venni. A munkáscsaládból érkezők 14,6\%-a (6fő) az első foglalkozását szemlélve alkalmazotti pozícióba került. A munkás helyzetből startolók túlnyomó része $(83,0 \%, 34$ fő) továbbvitte a szülook társadalmi állását, néhány esetben az apával ugyanolyan hivatást ủzve. Bali Zoltánnál, Györ-Moson vármegye főispánjánál (1948. május 29-tôl) a közös foglalkozás az asztalos (MOL 1954), Gábri Mihálynál, az MKP Győr városi titkáránál (1946. május 1-től), az MKP Győr Vármegyei Bizottság kádervezetőjénél (1946. július-1948. május) a lakatos ${ }^{5}$, míg Szabó György, a Győri Ideiglenes Nemzeti Tanácsban a munkástanács elnöke (1956. október 26-tól) esetében a nyomdász szakma volt (MOL 1951).

\section{TÁBLÁZAT \\ Elsö foglalkozás - kilépési mobilitás}

(First Occupation - Proportion of People Leaving a Given Social Group; Exit Rate of Mobility)

\begin{tabular}{lcccccc}
\hline \multirow{2}{*}{$\begin{array}{c}\text { Apa társadalmi } \\
\text { helyzete }\end{array}$} & \multicolumn{6}{c}{ Fiúllány elsö foglalkozása (kilépési mobilitási arányszám) \% } \\
& $\begin{array}{c}\text { Értelmi- } \\
\text { ségi }\end{array}$ & $\begin{array}{c}\text { Alkalma- } \\
\text { zott }\end{array}$ & $\begin{array}{c}\text { Iparos } \\
\text { /keresk. }\end{array}$ & Munkás & $\begin{array}{c}\text { Pa- } \\
\text { raszt }\end{array}$ & Összesen \\
\hline Értelmiségi & $71,4(5)$ & $28,6(2)$ & 0 & 0 & 0 & $100,0(7)$ \\
Alkalmazott & $14,3(1)$ & $28,6(2)$ & $14,3(1)$ & $42,8(3)$ & 0 & $100,0(7)$ \\
$\begin{array}{l}\text { Kisiparos/ } \\
\text { kiskereskedö }\end{array}$ & $22,2(4)$ & $16,7(3)$ & 0 & $61,1(11)$ & 0 & $100,0(18)$ \\
Munkás & $2,4(1)$ & $14,6(6)$ & 0 & $83,0(34)$ & 0 & $100,0(41)$ \\
Paraszt & $12,5(3)$ & $12,5(3)$ & 0 & $50,0(12)$ & $\begin{array}{c}25,0 \\
(6)\end{array}$ & $100,0(24)$ \\
& & & & & & $97 f o ̈$ \\
\hline
\end{tabular}

Forrás: Saját számítás.

A parasztcsaládok gyermekei $12,5 \%$-ának (3 fỏ) sikerült már pályafutása elejére a „nagy ugrást” megvalósítania, azaz az értelmiség rétegébe emelkednie (1. táblázat). Szarvas Imre, a Nemzeti Parasztpárt Győr-Sopron megyei titkára (1949-től) tanítóként (OSZK én.); dr. Kéri József, Győr-Sopron megye föügyésze (1955-1957) kollégiumi igazgatóként, majd tanársegédként ${ }^{6}$; míg Szili Ferenc, a győri Nemzeti Bizottság titkára (1946. augusztustól), az MKP Győr Városi Szervezete kádervezetője mérnökként tevékenykedett (OHA 1984, 40). Többükkel kapcsolatban elmondható, hogy egyetemi/föiskolai éveik alatt, elsősorban a nyári szünidőben, kénytelenek voltak munkát vállalni, hogy további tanulásukat biztosítsák. Alkalmazotti pozícióba ugyancsak hárman (12,5\%) kerültek: dr. Tézsla József, Győr-MosonPozsony k. e. e. vármegye alispánja (1946. június-1947. január) törvényszéki jegyzőként (OHA 1984, 11); dr. Szilágyi Gábor, Győr-Moson vármegye alispánja (1947. március-1950. április) jegyzőgyakornokként (majd segédjegyzőként) (MOL 1956); míg Lates József, az FKgP Győr városi elnöke (1946. szeptembertől), az FKgP Ideig- 
Varga Balázs : Az 1945-1956 közötti győri politikai és közigazgatási vezetöréteg származásifoglalkozási összetétele és mobilitási tendenciái. - Tér és Társadalom 24. évf. 2010/2. 45-61. p.

lenes Intézőbizottságának ügyvezetỏ alelnöke (1956. november 1-töl) gazdatisztként, illetve jószágkormányzóként dolgozott karrierje elején ${ }^{7}$. Szembetủnő, hogy a mezőgazdaságból élő családok fiainak pontosan fele $(50,0 \%, 12$ fö) a munkásság csoportjába került már a karrierje elejére. Társadalmi állását a kategóriába tartozók negyede (6 fö) örizte meg (1. táblázat).

Az ISA-paradigma alapján felvázolt kereszttáblázatokból a belépési mobilitási arányszámok is felvázolhatók, melyek azt fejezik ki, hogy a mintában az egy-egy kategóriába tartozók hogyan oszlanak meg származás szerint (2. táblázat).

Ez alapján elmondható, hogy az értelmiségiek $35,7 \%$-a (5 fö) értelmiségi, 7,1\%-a (1 fö) alkalmazotti, 28,6\%-a (4 fö) (kis)iparos/(kis)kereskedö, 7,1\%-a (1 fö) munkás, míg 21,5\%-a (3 fö) paraszti családból érkezett.

A karrierjük elején alkalmazotti beosztásban tevékenykedők 12,5\%-a (2f̋) értelmiségi, ugyancsak 12,5\%-a (2 fö) alkalmazotti, 18,7\%-a (3 fö) (kis)iparos/ (kis)kereskedö, 37,6\%-a (6 fö) munkás, míg 18,7\%-a (3 fö) mezőgazdasággal foglalkozó felmenőkkel rendelkezett.

A (kis)iparosként/(kis)kereskedőként dolgozók 100\%-a (1 fö), nevezetesen dr. Rácz Ferenc, az FKgP Győr városi alelnöke (1945-töl) olajkereskedő alkalmazotti családban született, hiszen édesapja városi föszámvevő volt (GYMSMGYL én.).

A munkás státuszba kerülök 5,0\%-a (3 fö) alkalmazotti, 18,3\%-a (11fó) (kis)iparos/(kis) kereskedö, 56,7\%-a (34 fö) munkás, ötöde (12fö) paraszti familiából érkezett.

A foglalkozási pályájuk elején parasztként dolgozók 100\%-a (6 fö) maga is paraszti családban látta meg a napvilágot.

\section{TÁBLÁZAT}

Elsö foglalkozás - belépési mobilitás

(First Occupation - Proportion of People Entering a Given Social Group)

\begin{tabular}{|c|c|c|c|c|c|c|}
\hline \multirow{2}{*}{$\begin{array}{c}\text { Apa } \\
\text { társadalmi } \\
\text { helyzete }\end{array}$} & \multicolumn{5}{|c|}{$\begin{array}{l}\text { Fiúllány elsö foglalkozása (belépési mobilitási arány- } \\
\text { szám) \% (fó) }\end{array}$} & \\
\hline & $\begin{array}{l}\text { Értelmi- } \\
\text { ségi }\end{array}$ & $\begin{array}{c}\text { Alkalma- } \\
\text { zott }\end{array}$ & $\begin{array}{l}\text { Iparos / } \\
\text { keresk. }\end{array}$ & Munkás & Paraszt & \\
\hline Értelmiségi & $35,7(5)$ & $12,5(2)$ & 0 & 0 & 0 & \\
\hline Alkalmazott & $7,1(1)$ & $12,5(2)$ & $\begin{array}{c}100,0 \\
(1)\end{array}$ & $5,0(3)$ & 0 & \\
\hline $\begin{array}{l}\text { Kisiparos/ } \\
\text { kiskereskedó }\end{array}$ & $28,6(4)$ & $18,7(3)$ & 0 & $18,3(11)$ & 0 & \\
\hline Munkás & $7,1(1)$ & $37,6(6)$ & 0 & $56,734)$ & 0 & \\
\hline Paraszt & $21,5(3)$ & $18,7(3)$ & 0 & $20,0(12)$ & $\begin{array}{l}100,0 \\
(6)\end{array}$ & \\
\hline Összesen & $100,0(14)$ & $100,0(16)$ & $\begin{array}{c}100,0 \\
(1)\end{array}$ & $100,0(60)$ & $\begin{array}{c}100,0 \\
(6)\end{array}$ & $97 f^{\prime \prime}$ \\
\hline
\end{tabular}

Forrás: Saját számítás.

Mint fentebb említettük, a mintába kerültek 51,5\%-a valósított meg mobilitást, azaz első (eredeti) foglalkozása eltért az apa társadalmi pozíciójától. Ezt az összes 
mobilitást, jelen esetben is, fel lehet osztani strukturális és cirkuláris mobilitásra. A strukturális mobilitáson azoknak az arányát értjük, akik szuikségképpen mobilak voltak a származási és az elért társadalmi helyzetek megoszlása közötti eltérés miatt, azaz azért kellett mobillá válniuk, mert az apák nemzedékének összetétele eltér a fiúk nemzedékének összetételétől. Megjegyzendő, hogy a társadalmi szerkezet változásán kívül az egyes társadalmi kategóriák eltérỏ gyermekszáma is a strukturális mobilitásban jelenik meg.

A kereszttáblázatok széleloszlásaiból kiindulva a strukturális mobilitás $36,1 \%$, ami viszonylag magas aránynak mondható. Az okok eléggé egyértelmủek. Magyarországon az 1930-as és 40-es években, és különösen az 1945 utáni időszakban, amikor a mintában szereplök döntő része munkába állt, a társadalmi-gazdasági struktúra jelentős változásokon ment keresztül. Az iparosodás-iparosítás maga után vonta a munkásság gyors ütemü létszámnövekedését. Elsősorban a társadalmi hierarchia legalján levő föld nélküli mezőgazdasági munkás, törpe- és kisbirtokos parasztok számára jelentette a proletarizálódás, rövidebb-hosszabb távon, a társadalmi felemelkedés csatornáját, így körükből nagy arányban (a mintában a paraszti származásúak 50,0\%-a) kerültek a munkásság csoportjába. Ezen kívül a (kis)iparos/ (kis)kereskedő családok gyermekeinél, különösképp a kommunista pártban tevékenykedő személyek között, figyelhetö meg a proletárrá válás jelensége (a mintában a kistulajdonosi háttérből érkezők 61,1\%-ból lett munkás már foglalkozási pályája elejére). Az értelmiségbe történő felemelkedés lehetőségei 1945 elött meglehetősen korlátozottak voltak. Leginkább a biztosabb egzisztenciával bíró középparaszti családok gyermekeinek adatott meg a diploma megszerzése és ez által szellemi hivatás betöltése. A szegényparaszti famíliák leszármazottainak legtehetségesebbjei csak elvétve tudtak ilyen gyors karriert megvalósítani. Az alkalmazotti háttérrel bírók 14,3\%-ából, míg a (kis)iparos/(kis)kereskedő családok gyermekeinek 22,2\%-ából lett értelmiségi. A munkás helyzetből startolókra a sajátos értékrendszer okán, melyben a tanulás, a taníttatás nem töltött be fontos szerepet, a korai szellemi hivatásúvá válás szinte egyáltalán nem volt jellemző.

A kereszttáblázat adataiból, pontosabban az összes és a strukturális mobilitás arányából kiindulva a cirkuláris, azaz a „helycserék” útján létrejött mobilitás a mintában $15,4 \%$.

A foglalkozás alapján történő felfelé és lefelé irányuló nemzedéken beluili mobilitás vizsgálata a mintában meglehetösen problematikus tủnik. Ha a politikai és a közigazgatási pozíciókat, funkciókat foglalkozásnak minősítjük, akkor egyértelmü, hogy minden egyes személy az eredeti hivatásához képest felfelé irányuló mobilitást valósított meg karrierje során, hiszen a különböző posztok által a helyi vagy akár az országos vezetörétegbe került és tartozott, hosszabb-rỏvidebb ideig az 1945 és 1956 közötti időszakban, esetleg azt követően is. Ha azonban az úgynevezett civil szakmák alapján tekintjük át a karrier-mobilitást, akkor egészen más képet kapunk. Ugyanakkor felmerülhet a kérdés, vajon mi minősül polgári foglalkozásnak. Mennyiben tekinthetjük civil hivatásoknak 1948-at követően az olyan, a politika által egyértelmủen befolyásolt tisztségeket, mint például a vállalatigazgatói vagy a 
termelöszövetkezeti elnöki poszt. Úgy gondoljuk, a leghelyesebb, ha a civil foglalkozásokhoz azokat a hivatásokat soroljuk, amelyeket az egyének csak a kellö iskolai végzettség és szakképzettség birtokában töltenek/tölthetnek be, legyen szó bármilyen politikai rendszerről is. Ha ebből a megközelítésböl kiindulva tekintjük át az eredeti foglalkozás és az életút során folytatott legmagasabb presztízsủ hivatás viszonyát, akkor meglehetősen alacsony mobilitási adatok rajzolódnak ki. Olyan, az eredeti foglalkozástól gyakran merőben eltérỏ szakmához, melyet karrierjük során bizonyos ideig gyakoroltak is, mindösszesen 9-en jutottak. Köztük elsősorban jogászokat (6 személy), mérnököket (2fö), valamint egy közgazdászt találunk.

A lefelé irányuló karrier-mobilitással (a civil foglalkozás alapján) szembesülők közé azokat soroltuk, akik az életpályájuk során valamikor az eredeti foglalkozásuknál alacsonyabb presztízsủ állásban voltak kénytelenek dolgozni. A mintában összesen 20 ilyen személy akad. Mindnyájan a politikai-közigazgatási funkciójuk elvesztését követôen (12-en 1956 után) kerültek az iskolai végzettségükkel és szakképzettségükkel nem harmonizáló munkakörbe. A legnagyobb „bukást” a diplomával rendelkező (értelmiségi) és az alkalmazott személyeknek kellett elszenvedniük. Egy-egy példát említve: a korábban ügyvédként praktizáló, majd népügyészként tevékenykedő dr. Alapy Gyulát 1956-ban mozdították el pozíciójából, melyet követően hosszú ideig villany- és gázóra leolvasóként dolgozott (ÁBTL-1 én.); míg az eredeti foglalkozására nézve tisztviselö Fertetics Ferenc (a Demokrata Néppárt Gyôr városi titkára 1948-ban) az ötvenes évek elejétől már mint gyári segédmunkás (tisztító) kereste kenyerét (ÁBTL-139 én.), és a sort hosszasan lehetne folytatni.

\section{Összegzés}

A tanulmányban arra tettünk kísérletet, hogy áttekintsük az 1945 és 1956 közötti győri politikai és közigazgatási vezetőréteg néhány szociológiai jellemzöjét (származást, eredeti foglalkozást és szakképzettséget, intergenerációs és intragenerációs mobilitást). A csoporthoz való tartozást szigorúan bizonyos pozíciók hozzárendelésével határoztuk meg, az 1945 és 1948 közötti időszakban, valamint 1956 októberében és novemberében az elit, míg az 1948 utáni korszakban a káder terminusát alkalmazva a mintába került egyénekre.

A teljes mintába összességében 140 föt vontunk be, melyet a források adatszegény volta miatt 119 före kellett csökkentenünk. A tanulmányban a kutatás megállapításait a mindenkori elérhetô mintával kapcsolatban tekintjük érvényesnek.

Az elözetes várakozásoknak megfelelöen a helyi vezetỏréteg meghatározó része (41,8\%-a) munkás családból származott. A munkás famíliákból érkezők édesapjainak túlnyomó része csak kevésbé megbecsült és rosszabb megélhetést biztosító segéd-, illetve betanított munkát végzett, tehát a munkásság csoportján belül is inkább az alsóbb rétegekben helyezkedett el. A társadalmi kategória magas reprezentáltsága azzal magyarázható, hogy a mintában nagy számban szerepeltek olyan 
Varga Balázs : Az 1945-1956 közötti győri politikai és közigazgatási vezetöréteg származási-

foglalkozási összetétele és mobilitási tendenciái. - Tér és Társadalom 24. évf. 2010/2. 45-61. p.

TÉT XXIV. évf. 2010 @ 2

Az 1945-1956 közötti ...

59

személyek, akik 1948-at követően töltöttek be helyben tisztséget, azaz olyan korszakban, mikor a káderek kiválasztásának egyik fő sajátossága a munkás (és paraszt) származás favorizálása volt. Az alkalmazott származásúakkal egyetemben a legkevésbé számos csoportot ( 7 fö, 7,1\%) az értelmiségi famíliába születettek alkották, kik között négy olyan személlyel találkozhattunk, aki az 1956-os forradalmi időszakban töltött be meghatározó pozíciót.

A helyi vezetöréteget az eredeti foglalkozás szempontjából elemezve a munkás hivatásúak dominanciáját (67 fó, a minta 59,3\%-a) tapasztaltuk. A második legszámosabb csoportot az alkalmazottak alkották (21 fö, 18,6\%). Szembeötlő volt a paraszt ( 6 fö, 5,3\%) és a kisiparos/kiskereskedỏ csoport (4 fö, 3,6\%) visszaszorulása a származásnál megfigyelt adatokhoz képest. Értelmiséginek 15 fö (13,3\%) minősült. A mintában leggyakrabban előforduló foglalkozások a következök voltak: fỏhivatású közigazgatási tisztviselő és közhivatalnok (12fö), lakatos(segéd) (9 fỏ), asztalos(segéd) és vasesztergályos(segéd) (8-8fo).

Az apák társadalmi helyzetének és a mintába kerültek eredeti foglalkozásának összevetése alapján elmondható, hogy a vezetőréteg tagjainak valamivel több, mint a fele $(51,5 \%)$ valósított meg intergenerációs mobilitást, mely egyértelmúen magas arányúnak mondható. Az immobilakat szemlélve megfigyelhetổ, hogy az értelmiségi apák gyermekei közül ( 7 fő) szinte mindenkinek ( 5 személy) sikerült, többek között a család kulturális tőkéjének segítségével, a társadalmi pozícióját megỏriznie. A mintában szereplők számára a legfőbb mobilitási iránynak egyértelmủen a munkássá válás tủnt, hiszen az alkalmazotti származásúak 42,8\%-a, a kisiparos/kiskereskedő családokból érkezők 61,1\%-a, míg a paraszt famíliák gyermekeinek 50\%-a eredeti foglalkozása alapján a munkásság társadalmi csoportjába sorolódott. Ugyancsak jellemzőnek mondható, hogy a munkás felmenőkkel bíró személyek domináns része $(83,0 \%$-a) továbbvitte apja társadalmi állását, míg az értelmiségbe történő belépés náluk tủnt a legkisebb mértékünek ( 1 fö, 2,4\%).

A foglalkozás alapján történő felfelé és lefelé irányuló intragenerációs mobilitás vizsgálata problematikusnak mutatkozott. A kutatásban a jelenséget az úgynevezett civil szakmák alapján tekintettük át. Polgári foglalkozásokhoz azokat a hivatásokat soroltuk, amelyeket az egyének csak kellő iskolai végzettség és szakképzettség birtokában tölthetnek be, legyen szó bármilyen politikai rendszerröl is. Ebből a megközelítésből szemlélve az eredeti foglalkozás és az életút során folytatott legmagasabb presztízsủ hivatás viszonyát, meglehetősen alacsony mobilitási adatok rajzolódtak ki. Mindössze 9 olyan személyt $(9,5 \%)$ találtunk a mintában, akik a fenti kritériumok alapján valósítottak meg nemzedéken belüli mobilitást. Lefelé irányuló foglalkozási mobilitással 20 fónek (16,8\%) kellett szembesülni élete folyamán. A legnagyobb „,bukást” azok az értelmiségi és alkalmazott személyek szenvedték el, akik karrierjük egy-egy szakaszában (segéd)munkásként voltak kénytelenek dolgozni.

A helyi vezetőréteg fentiekben taglalt ismérvein kívül kutatásaink során vizsgáltuk többek között a csoport tagjainak születési idő és születési hely szerinti megoszlását, iskolázottsági szintjét (az iskolai végzettség szintjét az első pozícióba kerülés idején és a teljes életpálya során megszerzett legmagasabb iskolai végzettséget), a 
házastárs hivatását, illetve a házastársak státusa közötti kapcsolatot, a gyermekszámot a szülöi és a saját családban, valamint az életutak sajátosságait (a vezetôrétegbe kerülés útjait - be-és kikerülést, a családi háttér, az iskola és a háborúk hatását), illetve a karrierpályák föbb típusait. Ezen témakörök tárgyalása azonban már újabb tanulmányok feladata.

\section{Jegyzetek}

${ }^{1}$ Forrás: Szabad Györ, 1945. június 19.

${ }^{2}$ Forrás: Győrmegyei Hírlap, 1949. május 10.

${ }^{3}$ A források egyikét a Györmegyei Hírlap 1949. május 11. száma jelenti.

${ }^{4}$ Amíg országosan általában a 20-50 holdas birtokhatárok között határozták meg a középparaszti gazdaságokat, addig az Alföldön azok alsó határa 20-30 hold közé esett, a Dunántúlon pedig már 10-20 hold között is lehetett találni hamisítatlan középparaszti gazdaságokat.

${ }^{5}$ Forrás: Györmegyei Hírlap, 1949. május 11.

${ }^{6}$ Forrás: Györmegyei Hírlap, 1949. május 10.

${ }^{7}$ Forrás: Szabad Györ, 1945. június 19.

\section{Irodalom}

ÁBTL-1 (én.) ÁBTL 3. 1. 5. O-14847/1 Fasiszta pártok, szervezetek és polgári pártok tagjai I. Állambiztonsági Szolgálatok Történeti Levéltára, Budapest.

ÁBTL-106 (én.) ÁBTL 3. 1. 5. O-14847/106 Lates József. Állambiztonsági Szolgálatok Történeti Levéltára, Budapest.

ÁBTL-139 (én.) ÁBTL 3. 1. 5. O-14847/139 Dr. Rácz Ferenc. Állambiztonsági Szolgálatok Történeti Levéltára, Budapest.

Bana J. (1997) Györ polgármesterei. - Városi Levéltári Füzetek. 1. 77-94. o.

Bana J.-Borbély J.-Szakolczai A. (szerk.) (1996a) Györ 1956. I. kötet. Dokumentumgyüjtemény. Györ Megyei Jogú Város Polgármesteri Hivatal, Győr.

Bana J.-Borbély J.-Szakolczai A. (szerk.) (1996b) Györ 1956. II. kötet. Dokumentumgyüjtemény. Györ Megyei Jogú Város Polgármesteri Hivatal, Győr.

Dávid L. (1971) A város a népi demokratikus forradalom idöszakában. - Dávid L.-Lengyel A.-Z. Szabó L. (szerk.) Györr. Várostörténeti tanulmányok. Győr Városi Tanács, Györ. 509-562. o.

Grábics F.-Horváth S.D.-Kucska F. (szerk.) (2003) Györi életrajzi lexikon. Galgóczi Erzsébet Városi Könyvtár, Györ.

Gyáni G.-Kövér Gy. (1998) Magyarország társadalomtörténete a reformkortól a második világháborúig. Osiris Kiadó, Budapest.

GYMSMGYL (én.) GYMSMGYL XXIII. 14. A Györ-Sopron megyei Tanács V. B. Munkaerỏgazdálkodási (munkaügyi) osztályának iratai. Személyi lapok. Dr. Szilágyi Gábor. GyőrMoson-Sopron Megye Győri Levéltára, Győr.

Győrmegyei Hírlap (1949) Győr, 1949. május 10. és május 11.

Kovács Győzőné (szerk.) (1975) Györ-Sopron megye forradalmi harcosainak életrajzgyüjteménye. MSZMP Györ-Sopron megyei Bizottsága, Győr.

Marelyn Kiss J.-Vida I. (szerk.) (2005) Az 1947. szeptember 16-ra Budapestre összehivott Országgyülés almanachja: 1947. szeptember 16.-1949. április 12. Magyar Országgyủlés, Budapest.

MOL (1951) MOL 276. f. 54. cs. 152. ő. e. 1951. július 18. Magyar Országos Levéltár, Budapest.

MOL (1953) MOL 276. f. 54. cs. 258. ő. e. 1953. augusztus 11. Magyar Országos Levéltár, Budapest.

MOL (1954) MOL 276. f. 54. cs. 341. ő. e. 1954. november 1. Magyar Országos Levéltár, Budapest.

MOL (1955a) MOL 276. f. 54 cs. 372. ö. e. 1955. július 11. Magyar Országos Levéltár, Budapest.

MOL (1955b) MOL 276. f. 54. cs. 371. ő. e. 1955. július 14. Magyar Országos Levéltár, Budapest.

MOL (1956) MOL 276. f. 54. cs. 408. ő. e. 1956. augusztus 28. Magyar Országos Levéltár, Budapest. 
Varga Balázs : Az 1945-1956 közötti győri politikai és közigazgatási vezetöréteg származásifoglalkozási összetétele és mobilitási tendenciái. - Tér és Társadalom 24. évf. 2010/2. 45-61. p.

TÉT XXIV. évf. 2010 『 2

Az. 1945-1956 közötti ...

61

MOL (1957) MOL 288. f. 5. cs. 33. ő. e. 1957. július 2. Magyar Országos Levéltár, Budapest.

MOL (1959) MOL 288. f. 7. cs. 61. ö. e. 1959. október 6. Magyar Országos Levéltár, Budapest.

OHA (1984) Kéri József-interjú. Készítette Hegedüs István 1984-ben. V 149. sz. 1956-os Intézet Oral History Archívuma, Budapest.

OHA (1986) Csatár Imre-interjú. Készítette Murányi Gábor 1986-ban. 20. sz. 1956-os Intézet Oral History Archívuma, Budapest.

OHA (1997a) Dr. Tóth István-interjú. Készítette Szakolczai Attila 1997-ben. 682. sz.1956-os Intézet Oral History Archívuma, Budapest.

OHA (1997b) Fekete József-interjú. Készítette Szakolczai Attila 1997-ben. 702. sz. 1956-os Intézet Oral History Archívuma, Budapest.

OSZK (én.) Interjú Szabó Györggyel. Columbia University Research Program for the Hungarian Revolution (CURPH), No. 253. 1956-os gyüjtemény. Országos Széchényi Könyvtár Kézirattára, Budapest.

Szabad Györ. (1945) Györ, 1945. június 19.

Varga B. (2003) Az 1945 elötti győri elit kapcsolatrendszerének mobilitása és változása a II. világháború utáni években. - Szretykó György (szerk.) A helyi társadalom szociológiai dimenziói. Comenius Bt., Pécs. 93-108. o.

Varga B. (2008) AZ 1945 és 1956 közötti gyóri politikai és közigazgatási vezetöréteg szociodemográfiai jellemzői. - Lörincz I. (szerk.) Apáczai Napok 2007. Értékörzés és értékteremtés. Tudományos konferencia. Tanulmánykötet. Nyugat-magyarországi Egyetem Apáczai Csere János Kar, Györ. 670-680. o.

Varga B. (2008) Az 1945-ös győri elitváltás „túlélői””. Három személyiségjegy, három fordulatos életút. - Györi Közélet. 33. 16-17. o.

\section{THE POLITICAL AND ADMINISTRATIVE ELITE OF GYŐR BETWEEN 1945 AND 1956 EXAMINED WITH REGARD TO THEIR SOCIAL BACKGROUND, OCCUPATION AND TENDENCY TO MOBILITY}

\section{BALÁZS VARGA}

This study aims to survey some sociostatistical attributes of the political and administrative elite of Györ in the years between 1945 and 1956. A detailed account is given concerning their social background, their original occupation and qualifications prior to their political career as well as their opportunities for both inter- and intragenerational mobility. The study, which was primarily based on archive materials, stated that a significant part of the local elite $(41,8 \%)$ came from a working-class family, while the smallest proportion of them $(7,1 \%$ respectively) had a clerical or intellectual background. Plenty of them were workers $(59,3 \%)$, while peasants $(5,3 \%)$ and craftsmen/retailers $(3,6 \%)$ were increasingly driven into background especially when compared to the data concerning their origin. Intergenerational mobility characterised more than half of the group $(51,5 \%)$, whereas the principal trend of mobility was a social one, that is becoming a member of the working class. 